\title{
Ex situ initial seedling development of Hymenaea courbaril L. (Fabaceae): a crucial phase to preserve the species
}

\author{
Patrícia Umeda Grisi ${ }^{1}$, Marieta Caixeta Dorneles ${ }^{2}$, ${ }^{\circledR}$ Marli Aparecida Ranal ${ }^{3,7}$, Ana Paula de Oliveira ${ }^{4}$, \\ Clesnan Mendes-Rodrigues ${ }^{5}$ and Denise Garcia de Santana ${ }^{6}$
}

Received: 7 August 2018; accepted: 10 June 2019

How to cite: Grisi, P.U., Dorneles, M.C., Ranal, M.A., Oliveira, A.P., Mendes-Rodrigues, C. \& Santana, D.G. 2019. Ex situ initial seedling development of Hymenaea courbaril L. (Fabaceae): a crucial phase to preserve the species. Hoehnea 46: e742018. http://dx.doi.org/10.1590/2236-8906-74/2018.

ABSTRACT - (Ex situ initial seedling development of Hymenaea courbaril L. (Fabaceae): a crucial phase to preserve the species). Hymenaea courbaril L. is an important Neotropical species, with low population density, restricted to fragments of semideciduous forests, with low mortality and low recruitment. Thus, some questions guided the goals of this paper including the capacity of stored seeds to form normal seedlings. Seeds collected from ten mother plants in the Brazilian Cerrado region and stored during three years were mechanically scarified, sown and analyzed during 43 days. Intraspecific variability was observed for water content, seed biometry, and emergence process. The seedling emergence varied from 19 to $92 \%$. Nine phases of development were observed. About $91 \%$ of the seedlings reached their complete autotrophy and this represents the success of the sample; the rest of the seedlings presented atypical morphology. This means that it is possible to store the seeds with the purpose of obtaining seedlings for ex situ cultivation. The great consumption of the cotyledon reserves occurred in the period that marks the alignment of cotyledons with hypocotyls (phases 1 to 4). For this species, if the seeds are scarified, the first 40 days after sowing are essential for the seedling establishment. After this time, the cotyledons fall signing a good point of reference for restoration projects because it indicates that the young plant is autonomous.

Keywords: Cerrado tree species, forest species, jatobá, resource allocation, seedling emergence

RESUMO - (Desenvolvimento inicial ex situ da plântula de Hymenaea courbaril L. (Fabaceae): uma fase crucial para preservar a espécie). Hymenaea courbaril L. é uma importante espécie Neotropical, que aparece com baixa densidade populacional, restrita a fragmentos de florestas semidecíduas, com baixa mortalidade e baixo recrutamento. Assim, algumas questões orientaram os objetivos deste trabalho, incluindo a capacidade de sementes armazenadas para formar mudas normais. Sementes coletadas de dez plantas-mãe na região do cerrado brasileiro e armazenadas durante três anos foram mecanicamente escarificadas, semeadas e analisadas durante 43 dias. Foi observada variabilidade intraespecífica para teor de água, biometria das sementes e para o processo de emergência. A emergência das plântulas variou de 19 a $92 \%$. Nove fases de desenvolvimento foram observadas. Cerca de $91 \%$ das mudas alcançou sua autotrofia e isso representa o sucesso da amostra. O restante das plântulas apresentou morfologia atípica. Isto significa que é possível armazenar as sementes com o propósito de obter plântulas para cultivo ex situ. O grande consumo das reservas cotiledonares ocorreu no período que marca o alinhamento de cotilédones com o hipocótilo, durante as fases 1 a 4 . Para esta espécie, se as sementes forem escarificadas, os primeiros 40 dias após a semeadura são essenciais para o estabelecimento das plântulas. Após esse tempo, os cotilédones caem e esse sinal é um bom ponto de referência para projetos de restauração, pois ele indica que a planta jovem está autônoma.

Palavras-chave: alocação de recursos, emergência de plântulas, espécies arbóreas do cerrado, espécies florestais, jatobá

1. Universidade Federal de São Carlos, Departamento de Botânica, Rodovia Washington Luís, km 235, SP-310, 13565-905 São Carlos, SP, Brasil

2. Universidade Federal de Uberlândia, Instituto de Biologia, Programa de Pós-Graduação em Ecologia e Conservação de Recursos Naturais, Avenida João Naves de Ávila 2121, 38400-902 Uberlândia, MG, Brasil

3. Universidade Federal de Uberlândia, Avenida João Naves de Ávila 2121, 38400-902 Uberlândia, MG, Brasil

4. Universidade Federal de Goiás, Campus Samambaia, Av. Esperança, s/n, 74690-900 Goiânia, GO, Brasil

5. Universidade Federal de Uberlândia, Faculdade de Medicina, Enfermagem, Avenida João Naves de Ávila 2121, 38400-902, Brasil

6. Universidade Federal de Uberlândia, Instituto de Ciências Agrárias, Avenida João Naves de Ávila 2121, 38400-902 Uberlândia, MG, Brasil

7. Autor para correspondência: marliranal@gmail.com 


\section{Introduction}

The disorderly exploitation of natural resources has caused degradation of areas in almost all Brazilian territory (Myers et al. 2000). This practice leads to the disappearance of several species in many regions (Pissarra et al. 2013), with serious impairment of genetic potential (Sebbenn et al. 1999).

The major problem in the restoration of native forests is the production of seedlings for the management and rehabilitation of degraded areas, maintaining ecological diversity which ensures the integrity of vegetable heritage (Perez 1995, Amaral et al. 1998).

Among the essential species for reforestation is Hymenaea courbaril L. (Fabaceae), a tropical tree with a natural distribution from the southern Brazilian coast to the western coast in the central region of Mexico, the Amazon Basin and particularly in the semideciduous forests of the Brazilian Central Plateau (Lacerda et al. 2008, Lopes et al. 2012a). Although generalist in relation to habitat (Lopes et al. 2012a), it is unfortunate that it frequently occurs in low population densities (Lacerda et al. 2008).

In the Ecological Station of Panga, Minas Gerais State, species recruitment of Hymenaea courbaril was zero for ten years (1997-2007) in 211 sampling plots of $10 \times 10 \mathrm{~m}$ and the mortality rate was $0.93 \%$ per year (Oliveira 2011, Oliveira et al. 2014). Normally the mortality and recruitment rate in stable forest communities is around $2 \%$ per year and close to or above $3 \%$ when the communities are more dynamic and are in areas with climatic seasonality (Carvalho 2009, Carvalho \& Felfili 2011). Thus, it appears that the population of this species shows low dynamics, besides its low density and scattering in the environment, as was pointed out by Lacerda et al. (2008) in the Pará State.

According to a survey made in 1994, the frequency of this species ranged from 1.3 to 2.6 tree $\mathrm{ha}^{-1}$ in a dry deciduous forest fragment, in the municipality of Perdizes, Triângulo Mineiro, MG (Werneck et al. 2000). In contrast, at the same place and in the same year, Anadenanthera colubrina (Vell.) Brenan, Mimosaceae, was found with the highest frequencies among the 114 species surveyed (223.1 to 207.7 tree $\left.\mathrm{ha}^{-1}\right)$. In a gallery forest of the Brasilia National Park, stocking of adult individuals $(\geq 15 \mathrm{~cm}$ diameter at breast height) of the Hymenaea courbaril was of 3.3 tree ha-1 (Leite 2001).
These population characteristics and the small stock of reproductive adults in natural environments can compromise the in situ conservation of genetic resources inherent to the species (Leite 2001). In this sense, the development of techniques for ex situ conservation is of great importance for the recovery of degraded areas and regeneration programs in areas where the species became rare or nonexistent. Due to deforestation and uncontrolled exploitation of its wood, Hymenaea courbaril is under risk of extinction and is included in the list of species considered priority by the Forestry Institute of São Paulo for ex situ genetic conservation (IPEF 2018). However, it is necessary to remember that seedling establishment is a decisive step in vegetation dynamics (Kidson \& Westoby 2000) and in natural conditions several risks diminish the chances of survival. Thus, ex situ seedling production is a solution for reforestation programs.

Due to the dimensions reached by the typical forest species (height and diameter), combined with good physical features in the wood, Hymenaea courbaril is among the most exploited wood species in the Brazilian Amazon (Lacerda et al. 2008). This is a serious problem, because tree species with long life spans are usually essential to forest ecosystems, and their genetic diversity is critical for the stability and sustainability of these ecosystems (Rajora \& Pluhar 2003). Moreover, it is recognized as a priority species for the conservation program of forest tree genetic resources besides being an economically and ecologically important tropical tree species of the Brazilian Atlantic rainforest (Feres et al. 2009).

Given the importance of Hymenaea courbaril in Neotropical forests, this species seems to be a very interesting biological model to study the early stages of seedling development. As it has large and orthodox seeds, with thick cotyledons, some questions guided the goals of this paper - (1) Is it possible to store seeds of $H$. courbaril with the purpose of obtaining seedlings for ex situ cultivation? (2) Are there differences among seeds produced by different mother plants in relation to water content, biometry and the emergence process? (3) What are the main phases of development of $H$. courbaril seedlings? (4) What is the frequency of each phase of development in one sample? (5) At what point during the seedling development, is there a greater consumption of cotyledon reserves?

\section{Material and methods}

Studied species - Hymenaea courbaril is a hermaphroditic, bat-pollinated tropical tree species 
with large seeds (ca. $5 \mathrm{~g}$ per seed), which ensure the supply of carbohydrates and proteins in the seedling establishment phase (Tiné et al. 2000, Santos \& Buckeridge 2004, Lacerda et al. 2008). This type of seed endures several environmental hazards (Kidson \& Westoby 2000, Baraloto et al. 2005). According to these authors, the tendency of the larger-seeded species is to have a lower concentration of mineral nutrients and a higher concentration of carbon reserves than smaller seeds. This condition allows the young plant to tolerate shade conditions for longer periods of time in the understory in relation to seedlings originated from small seeds. Thus, H. courbaril was classified as a shade-tolerant species (Paulilo \& Felippe 1998, Souza \& Válio 1999), occurring in low density, as a small population in fragmented environments (Toledo 2005). From an ecophysiology perspective, large seeds and large seedlings with slow development are associated with the capacity to adapt to shaded environments (Foster 1986, Westoby et al . 1992, Leishman \& Westoby 1994).

Sampling and study site - Seeds were collected from ten mother plants in the Araguari River Valley, Minas Gerais State, coordinates $\left(18^{\circ} 42^{\prime} \mathrm{S}\right.$ and $\left.48^{\circ} 27^{\prime} \mathrm{W}\right)$, in August (mother plants 1 to 6) and September 2005 (mother plants 7 to 10 ), according to mother plant production (figure 1). The regional climate is classified as tropical savanna (Aw Megathermic), according to the updated classification of Köppen-Geiger (Kottek et al. 2006), a tropical humid climate with a dry winter (April to September) and a rainy summer (October to

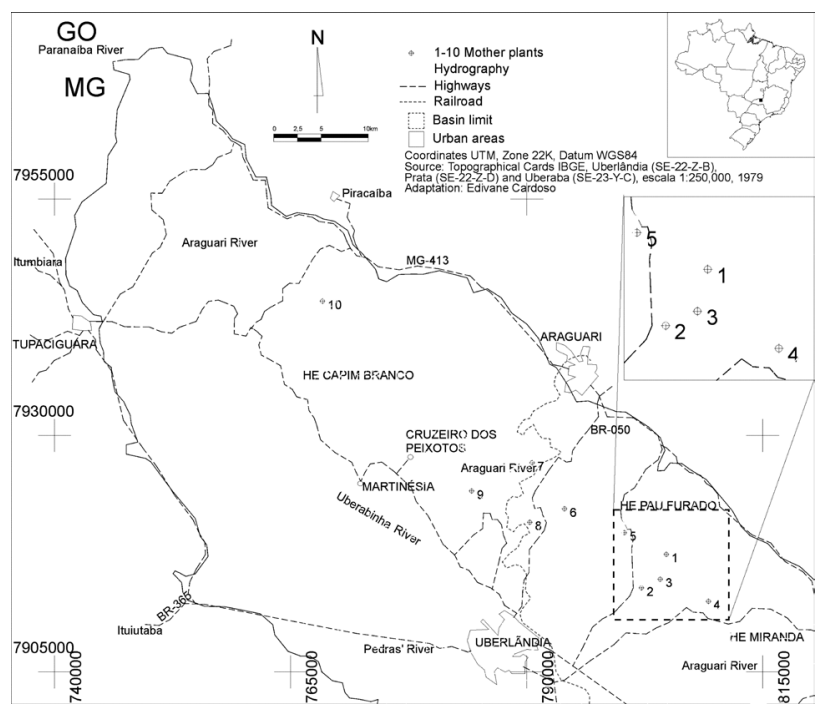

Figure 1. Distribution of the mother plants of Hymenaea courbaril L. (Fabaceae) in the Araguari River Valley, Minas Gerais State, Brazil.
March). The natural vegetation of the Araguari Valley was predominantly Cerrado, one of the hotspots for world biodiversity conservation (Myers et al. 2000), with its typical phytophysiognomies (Ribeiro \& Walter 1998). Presently, the natural cover is fragmented, with small remnants among predominantly large areas of pastures and crops (Scolforo \& Carvalho 2006). The area occupied by this type of vegetation in Brazil is underestimated due to its natural fragmented distribution, in general covering the slopes of interfluves between rivers, but this fragmentation has been accelerated by deforestation since the 1970s, giving it the status of one of the most threatened and fragmented ecosystems of the Earth (Lopes et al. 2012a, b).

Water content and biometry of seeds - One randomised sample of eight seeds per mother plant was evaluated (seed by seed) in relation to water content (drying at $70{ }^{\circ} \mathrm{C}$ ) until constant mass. The calculation was made using the dry basis. For seed biometry, one sample of 30 seeds per mother plant was evaluated. The means were compared by ANOVA or KruskalWallis tests, after applying Levene and Shapiro-Wilk tests for homogeneity and normality of the data. The data of seed width were root square transformed only for statistical analysis. Pearson linear correlations between the means of the dry mass and water content based on dry basis with seed biometry $(n=10)$ were calculated. For the seed biometry traits, Pearson linear correlations were calculated based on the residuals of ANOVA to correct individual effects based on Santana $\&$ Ranal (2006). The significance was evaluated with the Student's $t$-test at 0.05 . The adjectives to describe the magnitude of the correlations were used according to Davis (1971), where $r=0.01$ to 0.09 are negligible correlations, $r=0.10$ to 0.29 are low, $r=0.30$ to 0.49 are moderate, $r=0.50$ to 0.69 are substantial, $r=$ 0.70 to 0.99 are very high, and $r=1.0$ is the perfect correlation.

Seedling emergence - Seeds stored in a cold chamber for three years $\left(19.1 \pm 1.3^{\circ} \mathrm{C}\right.$ and $32.7 \pm 7.2 \%$ relative humidity) were scarified with an emery and sown in multi-cellular expanded polystyrene trays, with 72 cells containing vermiculite and commercial substrate Plantmax $^{\circledR}(1: 1)$. The seeds were sown at $2 \mathrm{~cm}$ depth, using one seed per cell. For each mother plant a random sample of 72 seeds was studied, totalling 10 samples distributed randomly on benches of a semiopen greenhouse installed under the shade of trees in the Experimental Garden of the Biology Institute, Federal University of Uberlândia. 
Based on the appearance of the aerial part of the seedlings, emergent plants were counted every 24 hours. Irrigation occurred daily. The minimum and maximum mean temperatures during the experimental period (November 20, 2008 to January 2, 2009) were 19.9 and $27.5^{\circ} \mathrm{C}$, respectively. Percentage of emergence $(E)$, time to first $\left(t_{f}\right)$ and last seedling emergence $\left(t_{l}\right)$, mean seedling emergence time $(\bar{t})$, uncertainty of seedling emergence $(U)$, the entropy associated to the distribution of the relative frequency of emergence through time, and the synchrony of seedling emergence $(Z)$ were calculated. The meaning, use and limitations of these measurements and the spreadsheets used for their calculations were presented by Ranal \& Santana (2006) and Ranal et al. (2009). Means of $E, \bar{t}$ and $U$ were compared using the Student's $t$-test at 0.05 of significance according to Santana \& Ranal (2004) and Carvalho et al. (2005). Pearson linear correlations between the means of the seed emergence measurements and the water content on dry basis of the seeds were made and the significance was evaluated with the Student's $t$-test at 0.05 .

Seedling development - Development phases were evaluated and quantified in 12-hour intervals, during 43 days from sowing, totalling 86 observations. Assessments of each experimental unit were interrupted when more than $50 \%$ of emerged seedlings reached phase 8 (seedling with cotyledons and hypocotyl in the same alignment and fully expanded leaf area). This experimental censure, that is, the interruption of the evaluations, was necessary because the first cotyledon of one seedling fell naturally. In this phase, the cotyledons are weakly attached to the hypocotyl, so minimum seedling manipulation is sufficient for it to drop, affecting the subsequent surveys. From the data obtained, we calculated the percentage of seedlings at each stage of development and the relative frequency of each development phase through time, adapted from Labouriau \& Valadares (1976) as

$$
f_{i}=n_{i}\left(\sum_{i=1}^{k} n_{i}\right)^{-1}
$$

where $f_{i}$ : relative frequency of each seedling phase at time $i ; n_{i}$ : number of seedlings emerged at time $i$, and $k$ : last time of observation.

Criterion to consider seedling - From the morphological point of view, the embryo is a set of structures formed by successive mitoses from the sexual or asexual zygote. From the moment that this embryo ruptures the surrounding tissues, teguments and endosperm, it becomes a seedling. However, it is difficult to say when one seedling passes from this stage to the one of young plant. Some authors consider this limit the fall of the cotyledons, when autotrophy ensures the survival of the new individual. For convenience, this will be the criterion used in this work. A good review on this subject is presented by Souza et al. (2009).

Seedling dry mass - At the end of the experimental collections the seedling dry mass was evaluated for the seven early stages of development ( $n=5$ seedlings of each phase, collected randomly, regardless of the original mother plant). The seedlings were dried until constant mass at $70^{\circ} \mathrm{C}$. The cotyledons were removed and evaluated separately from the other parts of the seedling to check the percentage of their consumption during development. The relative conservation of the cotyledons was calculated according to the expression $\mathrm{RCC}=$ (mass of the cotyledons of the seedlings in the phase $i /$ mass of the cotyledons of the seedlings in the phase 1) 100, where $i$ represents the evaluated phase. The dry mass ratio between cotyledons and the total mass of the seedling (cotyledons, root, hypocotyl and leaves, when they were present) was also calculated.

\section{Results}

The water content of seeds of Hymenaea courbaril stored in cold chamber for three years, around $10 \%$, is typical of orthodox seeds. This character and the biometry of the seeds were different among the ten mother plants evaluated (table 1). The greater the length and thickness, the greater the mass of the seed (very high and positive correlation between length and fresh mass; thickness and dry mass) and the greater the thickness, the lower the water content (very high and negative correlation between both characters; see table 2).

Although without mechanical dormancy due to the scarification, the seeds showed intraspecific variability in relation to the percentage of emergence, mean emergence time and uncertainty of emergence, and the process was asynchronous, with uncertainty values far from zero and $Z$ values near zero (table 3 ). The highest percentage of emergence was $91.7 \%$ and the lowest $19.4 \%$. The first emergence took 13 days and the last 41 days. The percentage of emergence had a negative and substantial correlation with the water content of the seeds, showing that the higher the 
Table 1. Water content on dry basis $(n=8)$ and biometry $(n=30)$ of the Hymenaea courbaril L. (Fabaceae) seeds collected from ten mother plants established in the Araguari River Valley, Minas Gerais State, Brazil, and stored during three years. ${ }^{1}$ Levene test and probability at 0.01 for homogeneity of variances; $W(P)$ : Shapiro-Wilk test and probability at 0.01 for normality; ${ }^{2}$ Snedecor test and probability at $0.05 ; H(P)$ : Kruskal-Wallis test and probability at 0.05 . Means with the same letter in the column are different according to Tukey or Dunn test at 0.05 . The values represent means \pm standard deviation.

\begin{tabular}{cccccc}
\hline Mother plant & Water content $(\%)$ & Length $(\mathrm{mm})$ & Width $(\mathrm{mm})$ & Thickness $(\mathrm{mm})$ & Mass $(\mathrm{g})$ \\
\hline 1 & $9.07 \pm 0.25 \mathrm{~d}$ & $23.18 \pm 1.77 \mathrm{c}$ & $20.39 \pm 3.01 \mathrm{a}$ & $12.94 \pm 2.66 \mathrm{ab}$ & $4.20 \pm 0.75 \mathrm{~cd}$ \\
2 & $10.28 \pm 0.63 \mathrm{abc}$ & $22.47 \pm 2.06 \mathrm{c}$ & $18.68 \pm 1.60 \mathrm{bcd}$ & $9.16 \pm 2.90 \mathrm{~d}$ & $2.79 \pm 0.71 \mathrm{f}$ \\
3 & $9.85 \pm 0.32 \mathrm{abcd}$ & $26.24 \pm 2.00 \mathrm{~b}$ & $18.83 \pm 1.82 \mathrm{abcd}$ & $12.83 \pm 2.23 \mathrm{a}$ & $4.38 \pm 0.48 \mathrm{bc}$ \\
4 & $9.78 \pm 0.41 \mathrm{bcd}$ & $27.55 \pm 1.42 \mathrm{ab}$ & $19.83 \pm 1.56 \mathrm{ab}$ & $13.30 \pm 1.79 \mathrm{a}$ & $4.94 \pm 0.64 \mathrm{ab}$ \\
5 & $9.40 \pm 0.68 \mathrm{bcd}$ & $28.91 \pm 3.06 \mathrm{ab}$ & $18.48 \pm 1.44 \mathrm{bcd}$ & $13.31 \pm 1.69 \mathrm{a}$ & $5.25 \pm 0.83 \mathrm{a}$ \\
6 & $9.39 \pm 0.60 \mathrm{~cd}$ & $23.03 \pm 2.27 \mathrm{c}$ & $17.73 \pm 1.54 \mathrm{~d}$ & $11.98 \pm 2.50 \mathrm{abc}$ & $3.73 \pm 0.84 \mathrm{de}$ \\
7 & $10.66 \pm 0.79 \mathrm{a}$ & $30.13 \pm 3.00 \mathrm{a}$ & $19.72 \pm 1.63 \mathrm{abc}$ & $10.86 \pm 1.93 \mathrm{bcd}$ & $4.97 \pm 1.14 \mathrm{ab}$ \\
8 & $10.39 \pm 0.88 \mathrm{ab}$ & $23.01 \pm 1.73 \mathrm{c}$ & $18.31 \pm 1.58 \mathrm{~cd}$ & $10.76 \pm 2.02 \mathrm{bcd}$ & $3.48 \pm 0.41 \mathrm{ef}$ \\
9 & $9.48 \pm 0.33 \mathrm{bcd}$ & $23.76 \pm 2.50 \mathrm{c}$ & $17.60 \pm 1.81 \mathrm{~d}$ & $12.56 \pm 1.28 \mathrm{ab}$ & $3.93 \pm 0.72 \mathrm{cde}$ \\
10 & $9.49 \pm 0.79 \mathrm{bc}$ & $27.17 \pm 2.22 \mathrm{ab}$ & $17.49 \pm 1.77 \mathrm{~d}$ & $10.92 \pm 1.39 \mathrm{~cd}$ & $3.96 \pm 0.61 \mathrm{cde}$ \\
${ }^{I} F(P)$ & $\mathbf{2 . 4 2 2 1}(0.0187)$ & $3.4120(0.0005)$ & $\mathbf{1 . 2 9 0 0}(0.2416)$ & $3.424(0.0010)$ & $3.5640(0.0003)$ \\
$W(P)$ & $\mathbf{0 . 9 5 8 2}(0.0364)$ & $\mathbf{0 . 9 8 6 2}(0.7205)$ & $\mathbf{0 . 9 7 3 4}(0.0137)$ & $0.972(0.0010)$ & $\mathbf{0 . 9 8 3 9}(0.5129)$ \\
${ }^{2} F(P)$ & $\mathbf{5 . 6 9}(0.0001)$ & - & $\mathbf{8 . 8 4 6}(0.0001)$ & - & - \\
$H(P)$ & - & $\mathbf{1 8 2 . 9 7}(0.0001)$ & - & $\mathbf{8 3 . 5 3}(0.0001)$ & $\mathbf{1 5 2 . 4 8}(0.0001)$ \\
\hline
\end{tabular}

Table 2. Coefficient of linear correlation ( $r$ ) between seed biometry and water content of Hymenaea courbaril L. (Fabaceae). Seeds collected from ten mother plants established in the Araguari River Valley, Minas Gerais State, Brazil, and stored during three years. $* * P<0.01$ and $* P<0.05$ for Student's $t$ test. WC: water content of the seeds on dry basis.

\begin{tabular}{|c|c|c|c|c|c|c|}
\hline \multirow[b]{2}{*}{ Character } & \multicolumn{6}{|c|}{ Character } \\
\hline & Length & Width & Thickness & Fresh mass & Dry mass & WC \\
\hline Width & $0.494 * *$ & & & & & \\
\hline Thickness & $-0.127^{*}$ & $-0.144^{*}$ & & & & \\
\hline Fresh mass & $0.687 * *$ & $0.514 * *$ & $0.346^{* *}$ & & & \\
\hline Dry mass & $0.5770^{*}$ & 0.1208 & $0.7205^{* *}$ & $0.8298 * *$ & & \\
\hline WC & 0.1895 & 0.1271 & $-0.7411^{* *}$ & -0.1459 & -0.4433 & \\
\hline
\end{tabular}

water content of the seeds, the lower the percentage of emergence ( $r=-0.746$, table 3$)$.

The nine phases of development of the seedlings are described in table 4 and presented in figure 2. For our analyzed sample, $19.58 \%$ of the seedlings had the elongation of the hypocotyl as the first event (phases $1-5$ ), followed by the distension of the first leaf (phases 6 to 8 ). These $19.58 \%$ represent the more vigorous seedlings, moving themselves away from the soil and leaf litter, which ensures better light capture. The greater consumption of the reserve material included in the cotyledons occurred during the alignment of the cotyledons with the hypocotyls, making this phase crucial for this species (phases 1 to 4; see last column table 5).
About $91 \%$ of the seedlings were successful, reaching phase 8 , with the hypocotyl completely distended and the first leaves expanded. When the first cotyledon fell, only one seedling reached phase 9 , but the seedlings in phase 8 had conditions to pass to phase 9 , because some months after the conclusion of the evaluations all young plants still continued their development.

The delayed seedlings (about 9\%; see figure 3) presented a short hypocotyl due to its slower distension in relation to the leaf expansion (both events occurred at the same time) and seemed to show the effort of the seedling to become autotrophic, although near the soil. The eophylls in expansion became stronger drains of the cotyledon reserves in relation 
Table 3. Emergence of Hymenaea courbaril L. (Fabaceae) seedlings (mean \pm standard deviation). Seeds collected from ten mother plants established in the Araguari River Valley, Minas Gerais State, Brazil, stored during three years and mechanically scarified before sown. $Z$ is expressed without the dispersion measurement because there is no mathematical expression for its variability, when calculated for samples. $E$ : percentage of emergence; $t_{f}$ : time to first emergence; $t_{l}$ : time to last emergence; $\bar{t}$ : mean emergence time; $U$ : uncertainty of emergence; $Z$ : synchrony of emergence. Means with different letters in the column are different according to Student $t$-test. $r$ : coefficient of linear correlation between seed emergence measurements and water content on dry basis, ${ }^{*} P<0.05$ for Student's $t$ test.

\begin{tabular}{|c|c|c|c|c|c|c|}
\hline Mother plant & $E(\%)$ & $t_{f}$ (day) & $t_{l}$ (day) & $\bar{t}($ day $)$ & $U$ (bit) & $Z$ \\
\hline 1 & $88.89 \pm 0.04 \mathrm{a}$ & 18 & 34 & $25.25 \pm 8.13 \mathrm{~d}$ & $3.05 \pm 0.02 \mathrm{a}$ & 0.1364 \\
\hline 2 & $37.50 \pm 0.06 \mathrm{c}$ & 20 & 35 & $26.22 \pm 11.79 \mathrm{e}$ & $3.09 \pm 0.02 \mathrm{a}$ & 0.0997 \\
\hline 3 & $72.22 \pm 0.05 b$ & 16 & 31 & $23.94 \pm 8.76 \mathrm{c}$ & $3.30 \pm 0.02 \mathrm{a}$ & 0.1018 \\
\hline 4 & $91.67 \pm 0.03 \mathrm{a}$ & 16 & 28 & $22.39 \pm 8.46 \mathrm{~b}$ & $3.38 \pm 0.01 \mathrm{a}$ & 0.0956 \\
\hline 5 & $90.28 \pm 0.03 \mathrm{a}$ & 13 & 41 & $19.94 \pm 21.93 \mathrm{a}$ & $3.69 \pm 0.02 b$ & 0.0841 \\
\hline 6 & $87.50 \pm 0.04 \mathrm{a}$ & 15 & 29 & $22.35 \pm 6.49 \mathrm{~b}$ & $3.12 \pm 0.02 \mathrm{a}$ & 0.1290 \\
\hline 7 & $19.44 \pm 0.05 \mathrm{~d}$ & 18 & 30 & $23.43 \pm 10.26$ bcde & $2.95 \pm 0.02 \mathrm{a}$ & 0.0879 \\
\hline 8 & $83.33 \pm 0.04 \mathrm{ab}$ & 14 & 38 & $22.50 \pm 9.88 \mathrm{~b}$ & $2.71 \pm 0.02 \mathrm{a}$ & 0.1684 \\
\hline 9 & $72.22 \pm 0.05 b$ & 18 & 28 & $22.37 \pm 22.37 \mathrm{~b}$ & $2.84 \pm 0.02 \mathrm{a}$ & 0.1501 \\
\hline 10 & $83.33 \pm 0.04 \mathrm{ab}$ & 17 & 30 & $24.60 \pm 7.06 \mathrm{de}$ & $3.28 \pm 0.02 \mathrm{a}$ & 0.1057 \\
\hline$r$ & $-0.746^{*}$ & 0.180 & 0.070 & 0.156 & -0.404 & -0.126 \\
\hline
\end{tabular}

Table 4. Morphology of seedlings of Hymenaea courbaril L. (Fabaceae) at different phases of development. Seeds stored during three years and mechanically scarified before sown. Percentage of seedlings in each phase, considering the total number emerged $(521=100 \%)$.

\begin{tabular}{ccc}
\hline Phase & $\%$ & Morphology \\
\hline 1 & 100.00 & Seedling with any portion of hypocotyl exposed above the substrate; cotyledons under the substrate \\
2 & 92.71 & Seedling with angle less than $90^{\circ}$ between cotyledons and hypocotyl \\
3 & 62.96 & Seedling with angle $90^{\circ}$ between cotyledons and hypocotyl \\
4 & 52.78 & Seedling with angle greater than $90^{\circ}$ between cotyledon and hypocotyl \\
5 & 19.58 & Seedling with cotyledons and hypocotyl in the same alignment \\
6 & 26.87 & Seedling with cotyledon and hypocotyl in the same alignment and up to 50\% of leaf area expanded \\
7 & 63.34 & Seedling with cotyledon and hypocotyl in the same alignment and with more than $50 \%$ of the leaf \\
area expanded
\end{tabular}

to the hypocotyl, which ensures autotrophy before the complete alignment of hypocotyl. However, this keeps the seedling near the soil and leaf litter, making it compete with other young plants for light in the understory.

The relative frequencies of the different phases of seedling development showed the dynamics and asynchrony of the development (figure 4). Phases 1 (amplitude $=672$ hours $=28$ days) and 4 (amplitude $=$ 552 hours $=23$ days) had the highest amplitudes (time of the phase appearance in the sample studied), indicating that these phases were present in the sample of 521 seedlings for a longer period of time in relation to the others.

The relative reduction of the cotyledons was greater in phase 4 than the others (table 5). The dry mass ratio between cotyledons and the total mass of the seedling decreased over time, showing mobilization of reserves for seedling formation (table 5). It is important to observe that in phase 7 the seedlings still had about $65 \%$ of their reserves for further development. 
Table 5. Allocation of dry mass in the seedling (mean $\pm \mathrm{SD}$ ) and conservation of the cotyledons of Hymenaea courbaril L. (Fabaceae) in relation to phase 1, at different phases of development. Seeds collected from ten mother plants established in the Araguari River Valley, Minas Gerais State, Brazil, stored during three years and mechanically scarified before sown. RHL: root, hypocotyl and leaves, when they were present. ${ }^{1}$ Cotyledons/TMS dry mass ratio. TMS: total mass of the seedling.

\begin{tabular}{ccccc}
\hline $\begin{array}{c}\text { Phase } \\
(n=5)\end{array}$ & Cotyledons $(\mathrm{g})$ & RHL $(\mathrm{g})$ & Ratio $^{1}$ & Relative conservation of cotyledons $(\%)$ \\
\hline 1 & $1.94 \pm 0.64$ & $0.10 \pm 0.04$ & $0.95 \pm 0.04$ & - \\
2 & $1.40 \pm 0.41$ & $0.25 \pm 0.04$ & $0.85 \pm 0.02$ & 72.16 \\
3 & $1.50 \pm 0.57$ & $0.28 \pm 0.08$ & $0.84 \pm 0.03$ & 77.32 \\
4 & $1.53 \pm 0.51$ & $0.33 \pm 0.06$ & $0.82 \pm 0.02$ & 78.86 \\
5 & $1.03 \pm 0.42$ & $0.30 \pm 0.10$ & $0.77 \pm 0.09$ & 53.09 \\
6 & $1.13 \pm 0.37$ & $0.38 \pm 0.06$ & $0.75 \pm 0.04$ & 65.46 \\
7 & $1.27 \pm 0.48$ & $0.47 \pm 0.16$ & $0.73 \pm 0.03$ & \\
\hline
\end{tabular}

\section{Discussion}

The water content of the newly collected seeds of Hymenaea courbaril was 9.4, 10, 10.6, 11.2, 12.9 and 13.5 for seeds of mother plants $6,4,2,5,7$ and 3 , respectively (Dorneles 2010). The seeds of mother plant number 6 maintained similar water content after three years, while seeds of mother plant number 3 lost nearly $4 \%$ of their water content. This explains the narrower limits observed for this character after three years of storage.

Although stored for three years, the seeds were in good physiological quality in relation to newly collected seeds. The percentage of emergence of scarified seeds in 2005 was 98.6, 79.2, 77.8, 100, 79.2, 86.1 and 5.6 for mother plants 1 to 7 , respectively (Dorneles 2010). The first emergence in 2005 occurred after six days of sowing and the last after 35 days, with the mean emergence time from 9.8 to 15.9 days, showing that the process became slower after three years of storage. After storage, the process also became more asynchronous ( $Z$ range in 2005 for scarified seeds evaluated every $24 \mathrm{~h}$ varied from 0.134 to 0.205 ), but with similar uncertainty ( $U$ range in 2005 for scarified seeds evaluated every $24 \mathrm{~h}$ varied from 2.0 to 3.0 bits). The ageing of the seeds may have been an important factor determining the greater asynchrony in the emergence process in relation to newly collected seeds, causing the anomaly of $9 \%$ of the seedlings (delayed emergence).

The seedling emergence of Hymenaea courbaril is slow and asynchronous even without mechanical dormancy, which was removed through mechanical scarification. The range between the first and last emergence, the higher mean emergence time and uncertainty, and lower $Z$ values in relation to other native species confirm this information, although there are slower and more asynchronous species than this (Carvalho et al. 2005, Pereira et al. 2009, Ranal et al. 2010, Mendes-Rodrigues et al. 2011a, b, Dorneles et al. 2013, Ribeiro-Oliveira et al. 2013, Berger et al. 2014, Ribeiro-Oliveira \& Ranal 2016).

The Hymenaea courbaril seedling is phanerocotylar-epigeal-reserve (PER), according to the criterion of Garwood (1996). Cotyledons that are on hypocotyl apex, sessile, bilateral, opposites, isophyllous and fleshy were also reported for $H$. intermedia Ducke var. adenotricha (Melo et al. 2004). The seedlings are also similar to those of $H$. parvifolia Huber and $H$. reticulata Ducke (Camargo et al. 2008).

The seedlings of species with large seeds are associated with their greater chance of survival (Kidson \& Westoby 2000, Baraloto et al. 2005). Although Hymenaea courbaril is a larger-seeded species that produces larger initial seedlings, giving them more chance to survive, the seedling growth is slower than smaller-seeded species as observed by Baraloto et al. (2005). The thick cotyledons ensure sufficient resources until the seedling becomes exclusively autotrophic, even with low relative growth rate and low light compensation points, which increases its ability to establish itself in forest environments (Kitajima 1994, Garwood 1996, Santos \& Buckeridge 2004, Brandão et al. 2009). This stage of development is crucial in the life history of a plant (Denslow 1980) and its survival, at this moment, is critical for the reproductive success of the species (Garwood 1996), especially given the high mortality recorded in the early stages of development (Souza \& Válio 2001, Bloor \& Grubb 2003). At this stage, many are the factors that influence its establishment, such as environmental conditions (nutrient availability, oxygen, water, light 

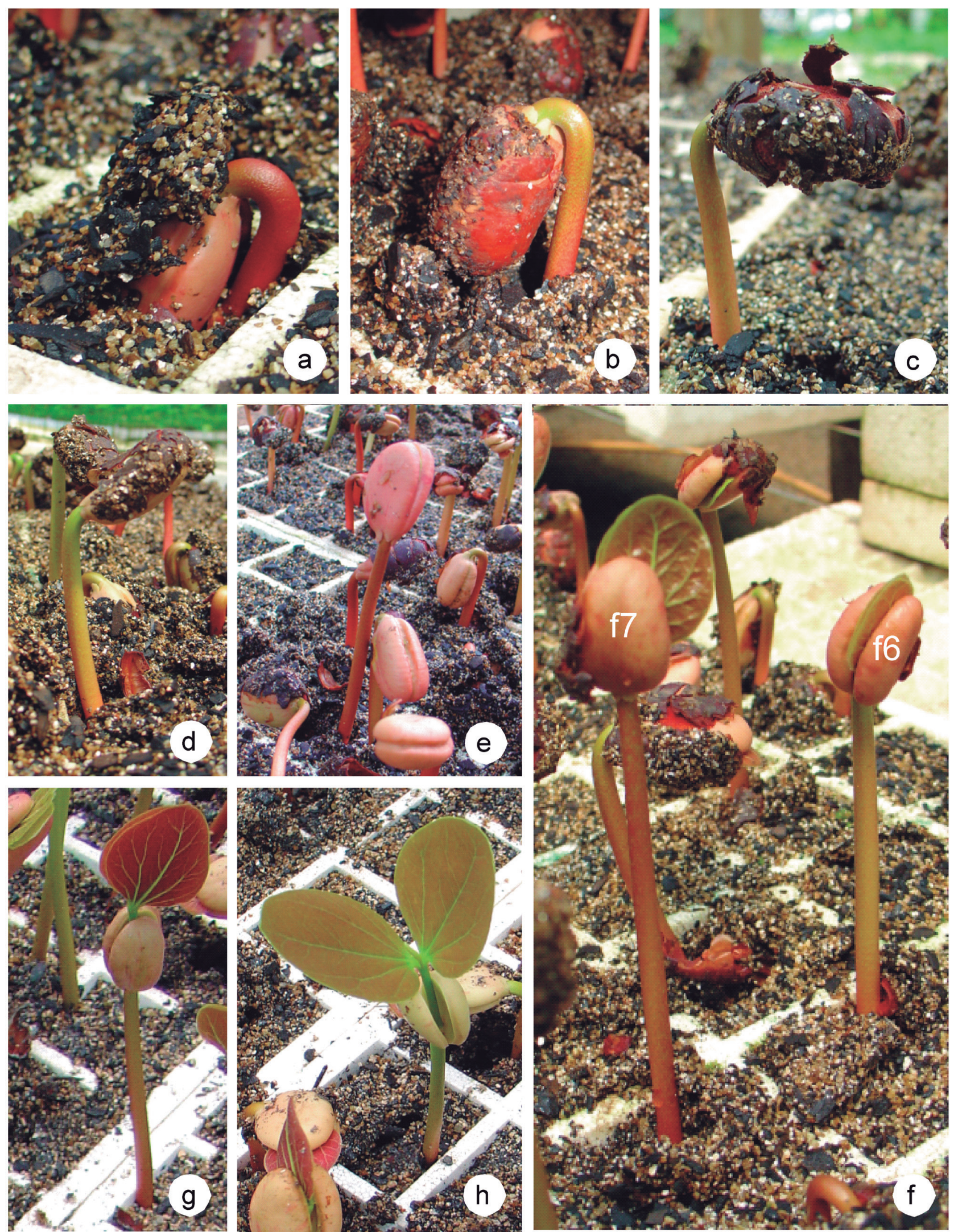

Figure. 2. Development phases of Hymenaea courbaril L. (Fabaceae) seedlings. (a) Phase 1; (b) phase 2; (c) phase 3; (d) phase 4; (e) phase 5; (f) phases 6 and 7; (g) phase 8; (h) phase 9. Seeds collected from ten mother plants established in the Araguari River Valley, Minas Gerais State, Brazil, stored during three years and mechanically scarified before sown. 

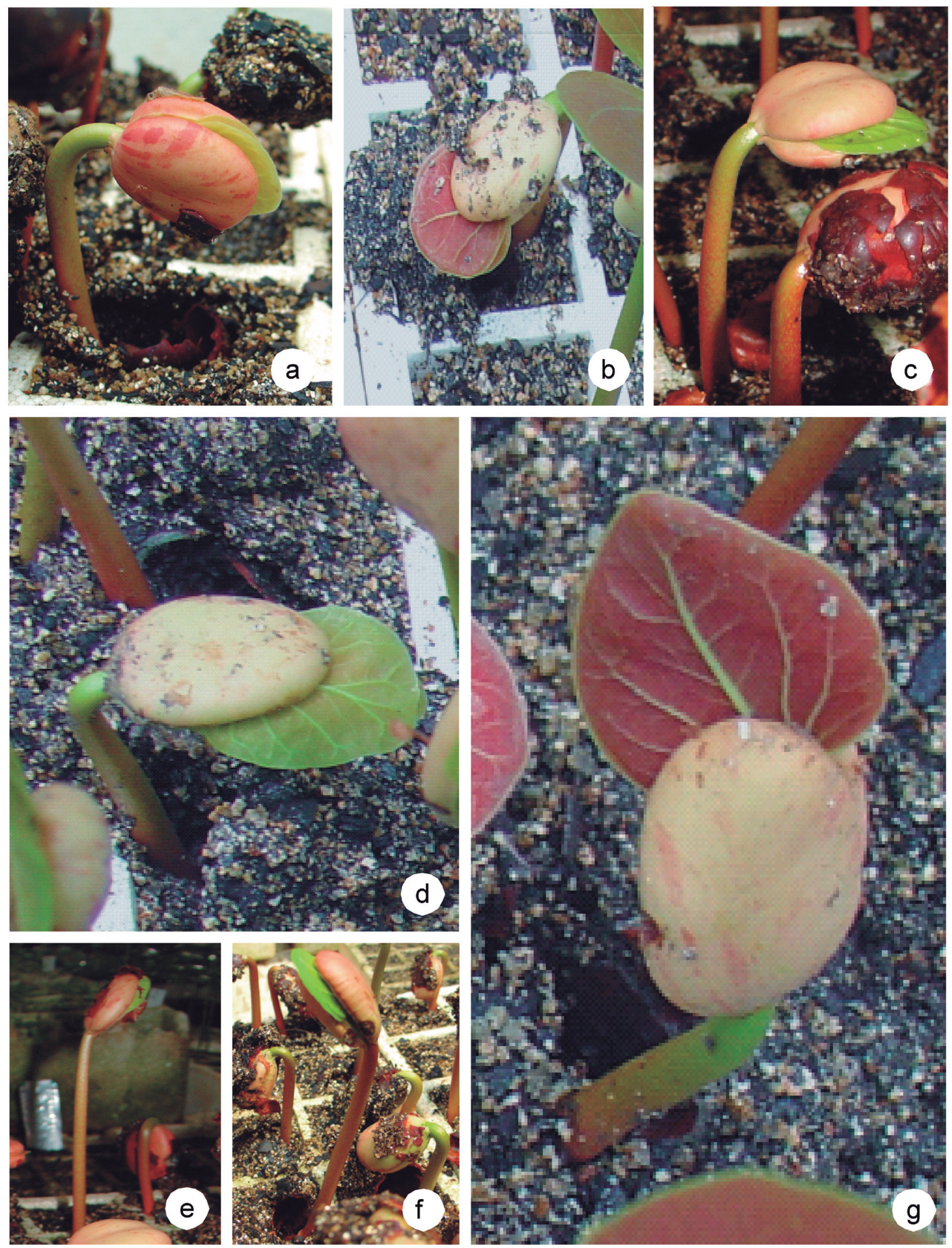

Figure 3 (a-g). Development of delayed Hymenaea courbaril L. (Fabaceae) seedlings showing the distension of the hypocotyl together with the leaf expansion. Seeds collected from ten mother plants established in the Araguari River Valley, Minas Gerais State, Brazil, stored during three years and mechanically scarified before sown. 

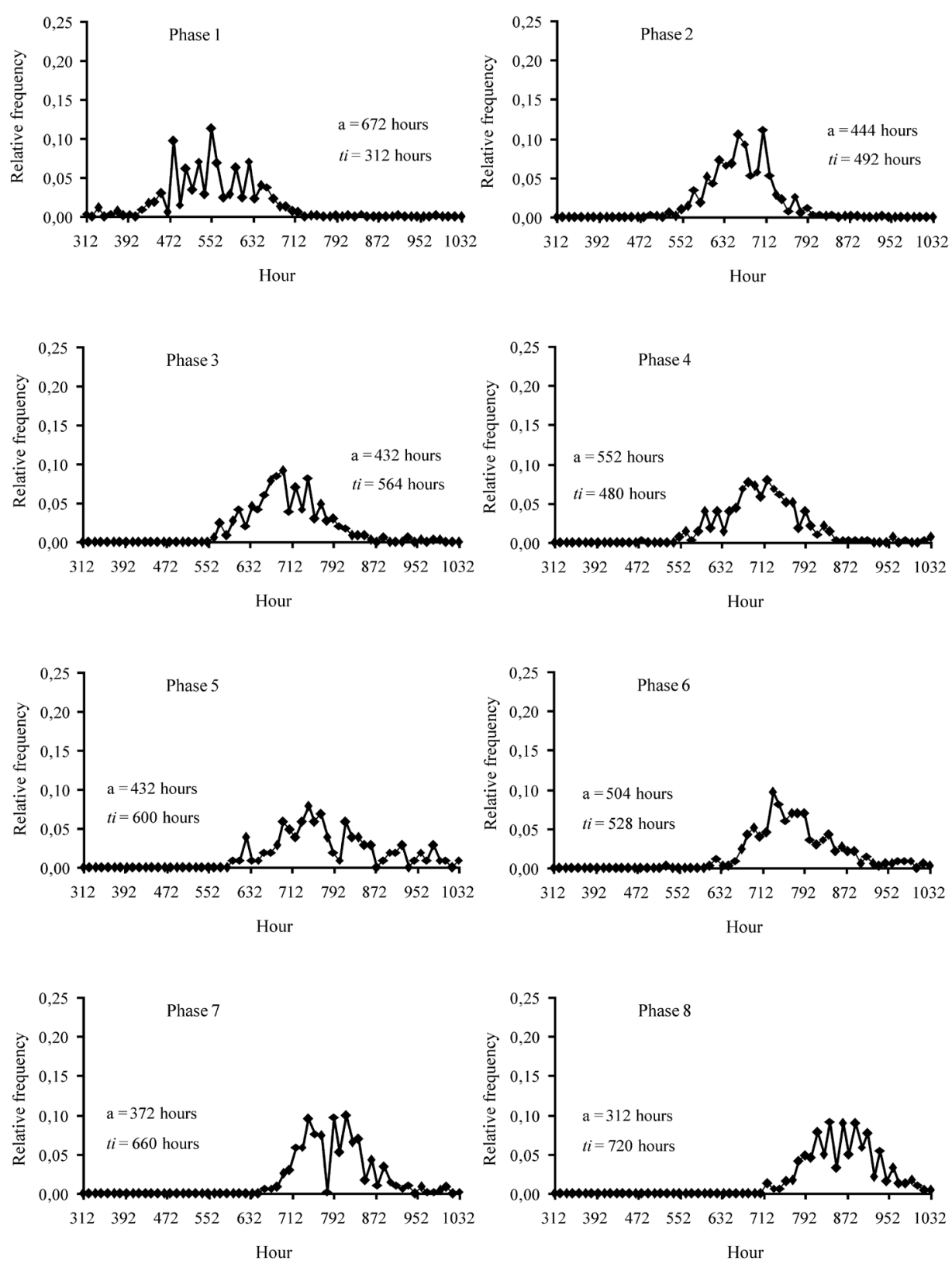

Figure 4. Relative frequency through time of the different phases of development of Hymenaea courbaril L. (Fabaceae) seedlings in the analyzed sample. Seeds collected from ten mother plants ( $n=720$ seeds; 521 seedlings emerged) established in the Araguari River Valley, Minas Gerais State, Brazil, stored during three years and mechanically scarified before sown. $t i$ : initial time of the phase. a: amplitude (difference between the last event and $t i$ ).

and temperature), physiological quality and vigour of the seeds (Whitmore 1996, Lüttge 1997).

For Hymenaea courbaril, mobilization of cotyledonary reserves begins immediately after seed imbibition and continues for about 50 days after sowing, when plants lose their cotyledons (Santos $\&$ Buckeridge 2004). The evaluations of our study were interrupted by the fall of the first cotyledon in the experiment (43 days after sowing), at which more than $50 \%$ of the emerged seedlings had cotyledons and hypocotyls in the same alignment and a fully expanded leaf area (phase 8). Thus, descriptions presented characterize the investment period of seedlings in the conversion of reserves, derived from the mother plant, into tissues for their formation and are within the range reported by Santos \& Buckeridge (2004). This means that initial establishment of seedlings involves the metabolically controlled use of reserve substances, until they are able to obtain environmental resources necessary for their growth and differentiation. 
Table 5. Allocation of dry mass in the seedling (mean $\pm \mathrm{SD}$ ) and conservation of the cotyledons of Hymenaea courbaril L. (Fabaceae) in relation to phase 1, at different phases of development. Seeds collected from ten mother plants established in the Araguari River Valley, Minas Gerais State, Brazil, stored during three years and mechanically scarified before sown. RHL: root, hypocotyl and leaves, when they were present. ${ }^{1}$ Cotyledons/TMS dry mass ratio. TMS: total mass of the seedling.

\begin{tabular}{ccccc}
\hline $\begin{array}{c}\text { Phase } \\
(n=5)\end{array}$ & Cotyledons $(\mathrm{g})$ & RHL $(\mathrm{g})$ & Ratio $^{1}$ & Relative conservation of cotyledons (\%) \\
\hline 1 & $1.94 \pm 0.64$ & $0.10 \pm 0.04$ & $0.95 \pm 0.04$ & - \\
2 & $1.40 \pm 0.41$ & $0.25 \pm 0.04$ & $0.85 \pm 0.02$ & 72.16 \\
3 & $1.50 \pm 0.57$ & $0.28 \pm 0.08$ & $0.84 \pm 0.03$ & 77.32 \\
4 & $1.53 \pm 0.51$ & $0.33 \pm 0.06$ & $0.82 \pm 0.02$ & 78.86 \\
5 & $1.03 \pm 0.42$ & $0.30 \pm 0.10$ & $0.77 \pm 0.09$ & 53.09 \\
6 & $1.13 \pm 0.37$ & $0.38 \pm 0.06$ & $0.75 \pm 0.04$ & 65.46 \\
7 & $1.27 \pm 0.48$ & $0.47 \pm 0.16$ & $0.73 \pm 0.03$ & \\
\hline
\end{tabular}

The cotyledons of Hymenaea courbaril store large amounts of xyloglucan (up 45\%) (Buckeridge \& Dietrich 1990, Amaral et al. 2012), a cell wall polysaccharide whose function has been shown to be the support of initial seedling growth and development until autotrophic growth is established (Santos \& Buckeridge 2004, Brandão et al. 2009). The mobilization of xyloglucan begins after imbibition and germination, when the shoot starts to develop, accompanied by increased production of fructose, glucose and sucrose and/or transient starch (Tiné et al. 2000). The stimulus for the degradation of xyloglucan in $H$. courbaril cotyledons probably comes from the shoot in the form of auxin stimulated by light (Santos et al. 2004, Brandão et al. 2009). In this species, the seed xyloglucan may have other functions, besides being a reserve, acting on the imbibition process, due to its hydrodynamic properties that control the advancement of water and promote protection against desiccation, and also participate in the control of seed predation (Santos 2002). The same author suggests that xyloglucan can be considered a key element within the evolutionary process for seedlings of this species to overcome physiological and biotic filters imposed by rainforests. For example, there is an increase in the importance of xyloglucan storage in cotyledons for $H$. courbaril seedling development as light intensity decreases, confirming that this polymer plays a key role in the adaptation of this species to the shadowed understorey of the forest (Santos \& Buckeridge 2004). Considering the importance of the seed reserves for this shade-tolerant species, the results here presented can generate an apparent paradox because the species is investing intensively in massive cotyledons that fall while still having high values of mass (about 65\%).
This can be an important strategy more related to the maintenance of the seeds in the soil for long periods of time than for the seedlings after leaf expansion. If they stay attached to the seedling, perhaps they could become harmful in the sense of being a strong attractor for herbivores and predators due to their high energetic potential, risking the survival of the seedling.

The results obtained answered the five questions asked at the beginning of the work. It is possible to store the seeds with the purpose of obtaining seedlings for ex situ cultivation, but after three years the $9 \%$ of atypical seedlings pointed out that this is the time limit for sowing to obtain new normal trees. All characters evaluated show variability among seeds produced by different mother plants. This means that the studied species still preserves genetic variation, despite its low frequency in the environment. Nine main phases of development characterized the initial growth of the species, including the elongation of the hypocotyls, followed by the distension of the first leaf. In relation to the phases, it is important to emphasize that about $91 \%$ of the seedlings reached phase 8 , with the hypocotyls and first leaves completely expanded.

It is not surprising that phases 1 and 4 were the longest during the development, because in phase 1 the seedling is using cotyledon reserves as a source of energy to emerge to the surface, with friction and cellular renovation in both shoots and roots, as well as the growth of the root system, which will ensure the supply of water and minerals, and physical support for the seedling. In phase 4, the seedling is probably investing in the enzymatic digestion of cotyledons for root system growth and alignment of the hypocotyl. The relative reduction of the cotyledons, greater in phase 4 than the others, is a good sign that confirm this assumption. 
For this species, if the seeds are scarified, the first 40 days after sowing are essential for the seedling establishment. During this period, the cotyledons represent the principal source of reserves for survival. After this time, the cotyledons fall and this signal is a good point of reference for restoration projects because it indicates that the young plant is autonomous.

\section{Acknowledgments}

We thank Roger Hutchings for the English review and good suggestions, and the anonymous reviewers for their positive criticism that improved the manuscript.

\section{Literature cited}

Amaral, L.I.V., Santos, H.P., Rossatto, D.R. \& Buckeridge, M.S. 2012. Diurnal changes in storage carbohydrate metabolism in cotyledons of the tropical tree Hymenaea courbaril L. (Leguminosae). Brazilian Journal of Botany 35: 347-355.

Amaral, P., Veríssimo, A., Barreto, P. \& Vidal, E. 1998. Floresta para sempre: um manual para a produção de madeira na Amazônia. Imazon, Belém.

Baraloto, C., Forget, P.-M. \& Goldberg, D.E. 2005. Seed mass, seedling size and neotropical tree seedling establishment. Journal of Ecology 93: 1156-1166.

Berger, A.P.A., Ranal, M.A. \& Santana, D.G. 2014. Variabilidade na dormência relativa dos diásporos de Lithraea molleoides (Vell.) Eng. Ciência Florestal 24: 1-13.

Bloor, J.M.G. \& Grubb, P.J. 2003. Growth and mortality in high and low light: trends among 15 shade-tolerant tropical rain forest tree species. Journal of Ecology 91: 77-85.

Brandão, A.D., Del Bem, L.E.V., Vincentz, M. \& Buckeridge, M.S. 2009. Expression pattern of four storage xyloglucan mobilization related genes during seedling development of the rain forest tree Hymenaea courbaril L. Journal of Experimental Botany 60: 1191-1206.

Buckeridge, M.S. \& Dietrich, S.M.C. 1990. Galactomannan from Brazilian legume seeds. Revista Brasileira de Botânica 13: 109-112.

Camargo, J.L.C., Ferraz, I.D.K., Mesquita, M.R., Santos, B.A. \& Brum, H.D. 2008. Guia de propágulos e plântulas da Amazônia. INPA, Manaus.

Carvalho, F.A. 2009. Dinâmica da vegetação arbórea de uma floresta estacional decidual sobre afloramentos calcários no Brasil Central. Tese de Doutorado, Universidade de Brasília, Brasília.
Carvalho, F.A. \& Felfili, J. M. 2011. Variações temporais na comunidade arbórea de uma floresta decidual sobre afloramentos calcários no Brasil Central: composição, estrutura e diversidade florística. Acta Botanica Brasilica 25: 203-214.

Carvalho, M.P., Santana, D.G. \& Ranal, M.A. 2005. Emergência de plântulas de Anacardium humile A. St.-Hil. (Anacardiaceae) avaliada por meio de amostras pequenas. Revista Brasileira de Botânica 28: 627-633.

Davis, J.A. 1971. Elementary survey analysis. Englewood, Prentice-Hall.

Denslow, J.S. 1980. Gap partitioning among tropical rainforest trees. Biotropica 12: 47-55.

Dorneles, M.C. 2010. Padrões de germinação dos diásporos e emergência das plântulas de espécies arbóreas do cerrado do Vale do Rio Araguari, MG. Tese de Doutorado, Universidade Federal de Uberlândia, Uberlândia.

Dorneles, M.C., Ranal, M.A. \& Santana, D.G. 2013. Germinação de sementes e emergência de plântulas de Anadenanthera colubrina (Vell.) Brenan var. cebil (Griseb.) Altschut, Fabaceae, estabelecida em fragmentos florestais do cerrado, MG. Ciência Florestal 23: 291-304.

Feres, J.M., Guidugli, M.C., Mestriner, M.A., Sebbenn, A.M., Ciampi, A.Y. \& Alzate-Marin, A.L. 2009. Microsatellite diversity and effective population size in a germplasm bank of Hymenaea courbaril var. stilbocarpa (Leguminosae), an endangered tropical tree: recommendations for conservation. Genetic Resources and Crop Evolution 56: 797-807.

Foster, S.A. 1986. On the adaptive value of large seeds for tropical moist forest trees: a review and synthesis. The Botanical Review 52: 260-299.

Garwood, N.C. 1996. Functional morphology of tropical tree seedlings. In: M.D. Swaine. (ed.). The ecology of tropical forest tree seedlings. Man and the Biosphere Series, v. 17. UK and USA, UNESCO and The Parthenon Publishing Group, pp. 59-129.

IPEF (Instituto de Pesquisas e Estudos Florestais). 2018. Identificação de espécies florestais. Available in http://www.ipef.br/identificacao/hymenaea.courbaril. asp (access in 07-I-2018).

Kidson, R. \& Westoby, M. 2000. Seed mass and seedling dimensions in relation to seedling establishment. Oecologia 125: 11-17.

Kitajima, K. 1994. Relative importance of photosynthetic traits and allocation patterns as correlates of seedling shade tolerance of 13 tropical trees. Oecologia 98: 419-428.

Kottek, M., Grieser, J., Beck, C., Rudolf, B. \& Rubel, F. 2006. World map of the Köppen-Geiger climate classification updated. Meteorologische Zeitschrift 15: 259-263. 
Labouriau, L.G. \& Valadares, M.E.B. 1976. On the germination of seeds of Calotropis procera (Ait.) Ait. f. Anais da Academia Brasileira de Ciências 48: 263-284.

Lacerda, A.E.B., Kanashiro, M. \& Sebbenn, A.M. 2008. Long-pollen movement and deviation of random mating in a low-density continuous population of a tropical tree Hymenaea courbaril in the Brazilian Amazon. Biotropica 40: 462-470.

Leite, E.J. 2001. Spatial distribution patterns of riverine forest taxa in Brasília, Brazil. Forest Ecology and Management 140: 257-264.

Leishman, M.R. \& Westoby, M. 1994. The role of large seed size in shaded conditions: experimental evidence. Functional Ecology 8: 205-214.

Lopes, S.F., Schiavini, I., Oliveira, A.P. \& Vale, V.S. 2012a. An ecological comparison of floristic composition in seasonal semideciduous forest in Southeast Brazil: implications for conservation. International Journal of Forestry Research 2012: 1-14.

Lopes, S.F., Schiavini, I., Vale, V.S., Prado Júnior, J.A. \& Arantes, C.S. 2012b. Historical review of studies in seasonal semideciduous forests in Brazil: a perspective for conservation. Brazilian Geographical Journal: Geosciences and Humanities Research Medium 3: 21-40.

Lüttge, U. 1997. Physiological ecology of tropical plants. Springer-Velag, Germany.

Melo, M.G.C., Mendonça, M.S. \& Mendes, A.M.S. 2004. Análise morfológica de sementes, germinação e plântulas de jatobá (Hymenaea intermedia Ducke var. adenotricha (Ducke) Lee \& Lang.) (LeguminosaeCaesalpinioideae). Acta Amazonica 34: 9-14.

Mendes-Rodrigues, C., Oliveira, P.E. \& Ranal, M.A. 2011a. Seed germination and seedling growth of two Pseudobombax species (Malvaceae) with contrasting habitats from Brazilian Cerrado. Revista de Biología Tropical 59: 1915-1925.

Mendes-Rodrigues, C., Ranal, M.A. \& Oliveira, P.E. 2011b. Does polyembryony reduce seed germination and seedling development in Eriotheca pubescens (Malvaceae: Bombacoideae)? American Journal of Botany 98: 1613-1622.

Myers, N., Mittermeier, R.A., Mittermeier, C.G., Fonseca, G.A.B. \& Kent, J. 2000. Biodiversity hotspots for conservation priorities. Nature 403: 853-858.

Oliveira, A.P. 2011. Dinâmica da comunidade arbórea de formações florestais do bioma cerrado no Triângulo Mineiro. Tese de Doutorado, Universidade Federal de Uberlândia, Uberlândia.

Oliveira, A.P., Schiavini, I., Vale, V.S. Lopes, S.F., Arantes, C.S., Gusson, A.E., Prado Júnior, J.A. \& Dias-Neto, O.C. 2014. Mortality, recruitment and growth of the tree communities in three forest formations at the Panga Ecological Station over ten years (1997-2007). Acta Botanica Brasilica 28: 234-248.
Paulilo, M.T.S. \& Felippe, G.M. 1998. Growth of the shrub-tree flora of the Brazilian cerrados: a review. Tropical Ecology 39: 165-174.

Pereira, R.S., Santana, D.G. \& Ranal, M.A. 2009. Emergência de plântulas oriundas de sementes recémcolhidas e armazenadas de Copaifera langsdorffii Desf. (Caesalpinioideae), Triângulo Mineiro, Brasil. Revista Árvore 33: 643-652.

Perez, S.C.J.G.A. 1995. Ecofisiologia de sementes florestais. Informativo Abrates 5: 13-30.

Pissarra, T.C.T., Marcussi, A.B., Leão, G.R., Galbiatti, J.A., Borges, M.J., Campos, S. 2013. Environmental adaptation of the source of the subbasin of Rico Stream, Monte Alto - SP, Brazil. Engenharia Agrícola 33: 303-311.

Rajora, O.P. \& Pluhar, S.A. 2003. Genetic diversity impact of forest fire, forest harvesting and alternative reforestation practices in black spruce (Picea mariana). Theoretical and Applied Genetics 106: 1203-1212.

Ranal, M.A. \& Santana, D.G. 2006. How and why to measure the germination process? Revista Brasileira de Botânica 29: 1-11.

Ranal, M.A., Santana, D.G., Ferreira, W.R. \& Mendes-Rodrigues, C. 2009. Calculating germination measurements and organizing spreadsheets. Revista Brasileira de Botânica 32: 849-855.

Ranal, M.A., Santana, D.G. \& Schiavini, I. 2010. Are there germination patterns for cerrado species? In: K.D. Claro, P.S. Oliveira, V. Rico-Gray, A.A.A. Barbosa, A. Bonet, F.R. Scarano, F.J. Morales Garzón, M.V. Sampaio, M.R. Morris, N. Ramírez, O. Marçal Júnior, R.H.F. Macedo, R.J. Marquis, L. Coelho, R.P. Martins, S.C. Rodrigues \& U. Lüttge (eds.). Encyclopedia of Life Support Systems. EOLSS Publication Catalogue. July 2010. Tropical Biology and Conservation Management, v. 10, Savannah Ecosystems, pp. 106-159. Available in http://www.eolss.net (access in 10-IX-2010).

Ribeiro, J.F. \& Walter, B.M.T. 1998. Fitofisionomias do bioma cerrado. In: S.M. Sano, S.P. Almeida (eds.). Cerrado: ambiente e flora. EMBRAPA, Planaltina, pp. 89-166.

Ribeiro-Oliveira, J.P. \& Ranal, M.A. 2016. Sample size in studies on the germination process. Botany 94: 103-115.

Ribeiro-Oliveira, J.P., Ranal, M.A. \& Santana, D.G. 2013. A amplitude amostral interfere nas medidas de germinação de Bowdichia virgilioides Kunth? Ciência Florestal 23: 623-634.

Santana, D.G. \& Ranal, M.A. 2004. Análise da germinação: um enfoque estatístico. Editora UnB, Brasília.

Santana, D.G. \& Ranal, M.A. 2006. Linear correlation in experimental design models applied to seed germination. Seed Science and Technology 34: 233-239. 
Santos, H.P. 2002. Importância ecofisiológica da reserva de xiloglucano e o controle de sua mobilização em cotilédones de Hymenaea courbaril L. Tese de Doutorado, Universidade Estadual de Campinas, Campinas.

Santos, H.P. \& Buckeridge, M.S. 2004. The role of the storage carbon of cotyledons in the establishment of seedlings of Hymenaea courbaril L. under different light conditions. Annals of Botany 94: 819-830.

Santos, H.P., Purgatto, E., Mercier, H. \& Buckeridge, M.S. 2004. The control of storage xyloglucan mobilization in cotyledons of Hymenaea courbaril L. Plant Physiology 135: 287-299.

Sebbenn, A.M., Siqueira, A.C.M., Kageyama, P.Y. \& Dio Junior, O.J.D. 1999. Variação genética entre e dentro de populações de amendoim - Pterogyne nitens. Scientia Forestalis 56: 29-40.

Scolforo, J.R.S. \& Carvalho, L.M.T. (eds.). 2006. Mapeamento e inventário da flora nativa e dos reflorestamentos de Minas Gerais. Editora UFLA, Lavras.

Souza, L.A., Moscheta, I.S., Mourão, K.S.M., Albiero, A.L.M., Montanher, D.R. \& Paoli, A.A.S. 2009. Morfologia da plântula e do tirodendro. In: L.A. Souza (org.). Sementes e plântulas: germinação, estrutura e adaptação. Todapalavra Editora, Ponta Grossa, PR, pp. 119-190.

Souza, R.P. \& Válio, I.F.M. 1999. Carbon translocation as affected by shade in saplings of shade tolerant and intolerant species. Biologia Plantarum 42: 631-636.
Souza, R.P. \& Válio, I.F.M. 2001. Seed size, seed germination, and seedling survival of Brazilian tropical tree species differing in successional status. Biotropica 33: 447-457.

Tiné, M.A.S., Cortelazzo, A.L. \& Buckeridge, M.S. 2000. Xyloglucan mobilisation in cotyledons of developing plantlets of Hymenaea courbaril L. (LeguminosaeCaesalpinoideae). Plant Science 154: 117-126.

Toledo, R.M. 2005. Modelagem espacial do fluxo de sementes de jatobá (Hymenaea courbaril) através de marcadores moleculares na paisagem fragmentada do Pontal do Paranapanema, SP. Tese de Doutorado, Universidade de São Paulo, São Paulo.

Werneck, M.S., Franceschinelli, E.V. \& Tameirão-Neto, E. 2000. Mudanças na florística e estrutura de uma floresta decídua durante um período de quatro anos (1994-1998), na região do Triângulo Mineiro, MG. Revista Brasileira de Botânica 23: 401-413.

Westoby, M., Jurado, E. \& Leishman, M. 1992. Comparative evolutionary ecology of seed size. Tree 7: 368-372.

Whitmore, T.C. 1996. A review of some aspects of tropical rain forest seedling ecology with suggestions for further enquiry. In: M.D. Swaine (ed.). The ecology of tropical forest tree seedlings. Parthenon Publishing Group, Paris, pp. 3-39. 